Article

\title{
Analyzing AgriFood-Tech e-Business Models
}

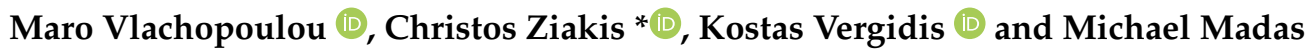 \\ Information Systems \& e-Business (ISEB) Lab, Department of Applied Informatics, University of Macedonia, \\ 54636 Thessaloniki, Greece; mavla@uom.edu.gr (M.V.); kvergidis@uom.edu.gr (K.V.); \\ mmadas@uom.edu.gr (M.M.) \\ * Correspondence: ziakis@uom.edu.gr
}

Citation: Vlachopoulou, M.; Ziakis, C.; Vergidis, K.; Madas, M. Analyzing AgriFood-Tech e-Business Models. Sustainability 2021, 13, 5516. https:/ / doi.org/10.3390/su13105516

Academic Editors: Maurizio

Canavari, Martin Hingley and Eliseo Luis Vilalta-Perdomo

Received: 10 April 2021

Accepted: 8 May 2021

Published: 14 May 2021

Publisher's Note: MDPI stays neutral with regard to jurisdictional claims in published maps and institutional affiliations.

Copyright: (C) 2021 by the authors. Licensee MDPI, Basel, Switzerland. This article is an open access article distributed under the terms and conditions of the Creative Commons Attribution (CC BY) license (https:// creativecommons.org/licenses/by/ $4.0 /)$.

\begin{abstract}
The agribusiness sector shows tremendous growth and sustainability prospects by exploiting the challenges of "AgriFood-Tech" business models in the digital environment, by encouraging innovation, accelerating institutional and structural change, enhancing productivity, and introducing new products and services to the market. The purpose of this study is to investigate different types of "AgriFood-Tech" digital models and analyze their role in the agribusiness and AgriFood sector. Based on relevant literature research, the authors present and discuss five indicative examples of "AgriFoodTech" models, using the Business Model Canvas (BMC) framework. The methodology included the analysis of the components of innovative AgriFood innovative business models paradigms, such as distribution channels, key partnerships, customer selection and relationships, financial viability, and value proposition. The goal was to explore their building blocks and the required decisions that create, deliver, and capture value. Our findings highlight the importance of specific features of the models, including online sharing of information between the stakeholders, online searches of agri-products, and logistics services in the agribusiness sector.
\end{abstract}

Keywords: "AgriFood-Tech" models; agribusiness sector; business model canvas; BMC framework; digital transformation in agriculture; innovative e-business models

\section{Introduction}

Nowadays, innovative e-business models enable the digital transformation of agricultural and AgriFood enterprises constituting the key to growth, given that, under certain conditions, they can contribute to national competitiveness, regional development, and recovery from the economic downturn. Furthermore, digitalization implies that innovative business models connecting the supply and demand in the broader value supply chain and food system, boost sustainability and employability, encourage new investment, and generate revenue streams.

The aim of this research was to investigate different types of "AgriFood-Tech" digital models along the supply chain and analyze their role in the agribusiness sector. Based on recent literature research, we present and discuss five indicative examples of "AgriFood-Tech" e-business models, using the Business Model Canvas (BMC) framework [1,2]. Specifically, five successful start-up companies in the AgriFood sector were selected according to the Forbes list, the SVG Ventures THRIVE Top 50 (https: / thriveagrifood.com, accessed on 19 April 2020) and similar web (https:/ / www.similarweb.com, accessed on 19 April 2020), for analysis using the BMC framework [3].

The methodology used was the analysis of structural modules of BMC with the aim of exploring innovations in representative AgriFood-Tech models that add value.

Highlighting disruptive business models that incorporate new technologies, we can identify the benefits and opportunities for an improved customer experience in the existing and new markets that reshape the AgriFood supply chain, and the relationship between the involved parties, such as farmers, brokers, technical supporters, financial institutions, agronomists, and food organizations; and customers, acting as buyers, sellers, 
and partners. Thus, incorporating cross-industry technologies and applications, such as data analytics, precision agriculture, mobile apps and IoT, cloud computing, artificial intelligence and blockchain technology as a sustainable and scalable resource, innovative models can support farmers, partners, and customers, increasing the integration, efficiency, and performance of transactions taking place along the entire AgriFood supply network.

The paper is organized as follows. In Section 2, we briefly discuss innovative Tech models that were recently developed and implemented in the AgriFood industry, mainly as start-ups, in order to set the theoretical background for the usability and the benefits of these AgriFood-Tech models. Then, we present the e-business models of five of the most popular and successful companies in the AgriFood sector as paradigms to be analyzed in Section 3, using the BMC components. Section 4 contains a discussion of the outcoming results, leading to implications of these models and technologies in the AgriFood sector, clarifying strengths, weaknesses, opportunities, and threats related to the models observed. Conclusion (Section 5), we present the benefits of using similar Tech e-business models, by taking into consideration the trends of the AgriFood ecosystem and we include suggestions for future research directions.

\section{Materials and Methods}

The AgriFood sector constitutes a complex ecosystem involving a highly heterogenous set of players, such as different profiles of farmers, growers, brokers, further supply chain partners, and consumers, operating in numerous interactions-e.g., production, information exchange, financial flow, supply chain and logistics, marketing and further service provision in different subsectors and geographical areas. Moreover, there are different types of farmers, including a large number of smallholder farmers across developing countries, who are cautious with brokers, are without any internet infrastructure, and do not have digital literacy. The problems that farmers are facing are diverse, ranging from lack of access to information related to inputs and markets, financing difficulties to lack of ability to analyze market data and forecast proper production, to name a few [4]. Additionally, the AgriFood sector and its supply chain management require specific actions due to concerns over the following factors [5]:

- Limited natural resources;

- Production of sensitive and seasonal products with a short life cycle, in different geographical areas;

- Several warehouse and transportation management alternatives, depending on the type of the product;

- Traceability and visibility needs;

- Changing consumer dietary demands; and

- Safety and public health concerns.

Understanding the AgriFood-Tech business models and helping to design and measure them is a challenging task that attracted the interest of researchers and practitioners, to facilitate timely and responsive support for the entities of the AgriFood ecosystem, regarding the above-mentioned issues.

In the wake of the digitizing Europe, the "DIVA project" is a European initiative focusing on disrupting digital models using technologies such as mobile apps, cloud, big data and analytics, artificial intelligence, blockchain, and electronic marketplaces, to provide support to the emergence and development of added value chains in the AgriFood sector [6].

Furthermore, SVG I THRIVE is the leading global AgriFood investment and innovation platform with a community of over 5000 start-ups from 100 countries, headquartered in Silicon Valley since 2010, and comprised of top agriculture, food and technology corporations, universities, and investors focusing on connecting involved organizations with emerging technologies and start-ups (https:/ / thriveagrifood.com, accessed on 19 April 2020). 


\subsection{AgriFood-Tech e-Business Models}

Several e-Business models appear in the AgriFood sector which serve different goals and apply new technologies. While there is a lot of activity in the agricultural technology landscape, leading to digital disruption, there are no clear frontrunners in terms of the specific type and technology a business solution incorporates. In this paper, beyond the farming processes, AgriFood-Tech models also include the support of food supply chain by digital technology systems in the process of transporting products from the farm to the consumer $[7,8]$.

Innovative business models embrace the core values of the Rappa business models and have many similarities, although they are more focused on start-ups. Below, we briefly refer to some basic models that were recently developed and implemented in a digital environment in the AgriFood sector [9]. e-Marketplace models connect farmers, partners, and consumers based on a platform to enable exchanges between the involved parties and access to information regarding trading markets and resources. Thus, according to the Brokerage business model, e-brokers develop a platform to enable the matching between potential buyers and sellers, and facilitate transactions by charging a fee or commission, acting in business-to-business (B2B), business-to-consumer (B2C), or consumer-to-consumer (C2C) markets [10]. Specifically, according to Rappa, different types of this model could be used [9].

It could be used as "Marketplace Exchange" which provides specific services during the whole process of the transaction, akin to a "Transaction Broker", undertaking a thirdparty payment system for trading parties, and as "Search Agent" or "robot", to find out specific information about the price and availability of a product.

Furthermore, "Become a Marketplace/Digital Marketplace/Sharing Economy" business models enable the matching via digital platforms between buyers and sellers in a two-sided market. These platforms focus on enabling an outcome faster, easier, and often cheaper than was previously possible. "Virtual Marketplace" models represent an alternative type of the above models, proving a hosting services for online merchants. "Virtual value-chain" models for agribusiness consider sharing of information as a value-creating opportunity, using multiple digital channels. "Infomediaries (information intermediaries)" business models gather and share focused information on behalf of farmers, and supply chain partners for AgriFood products and their potential customers. Regarding the "Insight services" model, companies monetize their data by placing them in a customer's context. They aggregate datasets and artificial intelligence to deliver proprietary insights with business APIs [11-13].

The "Subscription" model uses a periodically charged fee and it is common to provide a free membership with time, or access restrictions or a paid membership option, enabling the combination of a free trial or level of services and a "premium" one. In the last case, subscription fees are charged, regardless of the actual usage rates [14].

In the digital environment, the AgriFood sector explores business model innovations, including e-marketplaces that enhance customer experience and shorten supply chains, moving from transactional models to service-oriented ones [15]. Innovative e-business models evolved into complex, coherent, and integrated networks that coordinate key partnerships between a high number of participants throughout the supply chain, including customers, suppliers, intermediaries, and other business partners [16].

The Data-Driven (DD) model refers to organizations using data as a key resource for their business execution. Specifically, big data analysis drives cost-effective, innovative information processing, supporting enhanced analytics, insight, and decision-making. According to Ward and Baker [17], big data describe the storage and analysis of large and or complex datasets, using machine learning and artificial intelligence or data mining techniques [18].

A DD business model is not limited to companies that conduct analytics, but also includes companies that are collecting or aggregating farmers' data. Thus, Data as a Service refers to new ways of collecting, aggregating, and analyzing data, in order to organize 
a wide range of public and private data by the involved AgriFood parties and partners. Analytics as a Service refers to predictive, prescriptive, and cognitive analytics, which provide specific, timely, and actionable information to customers, leveraging analysis techniques and creating new information and knowledge from existing data, treating the data as an asset and providing opportunities to monetize data [19].

Cloud systems and SaaS (Software as a Service) provide opportunity for AgriFood players to pay a monthly fee instead of buying software, which provides access to it, while it is hosted on a cloud infrastructure [20]. Digital Transformation builds business models that enable win-win customer scenarios: a win for the customer, and a win for the manufacturer, leading towards "Everything-as-a-service" or "Capability-as-a-service" business model (called Xaas) in which customers only pay for the services or time that they actually use the product [21]. Companies deploying this model are replacing traditional business, boosting operational efficiency by low acquisition costs for their customers, implementing a new value proposition, and driving higher revenues. Advanced technologies supporting farmers are experimenting with new "Robotics-as-a-Service" models and "XaaS" models adding value to the traditional AgriFood supply chain [22].

McKinsey, in his study in 2018 on innovation in food processing, explores drivers of business model innovation and highlights that the increasing data availability leads companies to leverage advanced analytics to generate insights and learn how to run their businesses more efficiently $[23,24]$.

\subsection{AgriFood-Tech Paradigms}

In this section, we present the e-business models of five of the most popular and successful companies in the AgriFood sector according to their ranking in the SVG Ventures THRIVE Top 50 list [3]. The popularity of these models is determined by the company's estimated value according to the Forbes list with the most successful start-ups in the AgriFood sector between 2018 and 2020, the SVG Ventures THRIVE Top 50 ranking list (https: / thriveagrifood.com, accessed on 19 April 2020) and similar web, respectively (https:/ / www.similarweb.com, accessed on 19 April 2020) [4]. This is an annual ranking list of leading global Agri-Tech and Food-Tech companies illustrating the best in agriculture and food-focused innovation. The above list is based on criteria, such as: incorporating proven technology with product in market, customer engagement, revenue flow and established founding team with track record. Next, we examined the companies that continue their successful operation according to the 50 top start-ups from 2018 until today and each company's financial and agricultural credentials. Thus, we selected five examples of these most innovative start-ups in the ag-tech space that include innovative technologies and differ greatly in their functions, incorporated technology and business models. Next, we will refer to the selected companies (FoodLogiQ, Farmer's Business Network, FarmLead, Full Harvest and Farmers Edge), providing general information about their characteristics and purpose (https: / / thriveagrifood.com/startups/thrive-top-50/, accessed on 19 April 2020). In this way, we will be able to conduct a comparative analysis and we will come up with a result that will highlight these different business models to emphasize the added value of each one and the degree of success of each business model.

FoodLogiQ is an innovative company operating as a Software-as-a-Service (SaaS) food chain solution of the entire chain traceability, recall management and food safety compliance, all in a single platform. FoodLogiQ was also recognized in 2018 by Forbes Magazine as being one of the top 25 most innovative Agri-Tech start-ups. FoodLogiQ is taking the lead with blockchain exploration aiming to reduce food recall costs. Blockchain is not yet a proven solution in the food industry but holds tremendous promise on its potential to open transparency in the food supply chain [25]. FoodLogiQ customers include Whole Foods, Chipotle, Subway, Dave \& Buster's, Tropical Smoothie Cafe, Cava Grill, Robinson Fresh, Durst Organic Farms, Bailey Farms, the National Potato Council, Salandinos, and Golden State Foods among others. The FoodLogiQ Connect platform includes over 2000 
registered businesses in over 35 countries with 18,000 locations (Supply Chain Integration and Analytics model, Data-driven Business model, Data Analytics and AI, SaaS model).

The Farmer's Business Network (FBN) (https:/ / www.fbn.com/, accessed on 19 April 2020) is one of the most dominant Agri-Tech organizations, offering farmers, that pay a subscription fee, access to data and analytics providing insight on input prices, and market information. Moreover, farmers can use the online store of FBN Direct for their input with lower prices than their retail companies. Finally, before the planting season begins, the FBN signs contracts with farmers that guarantee them a buyer at harvest time. According to the value proposition of this model, farmers combine data with collective bargaining power, paying a monthly subscription fee (https: / / www.fbn.com/analytics\#mobile-apps, accessed on 19 April 2020) (Big Data, Subscription model, Data-Driven business model).

FarmLead is a grain e-marketplace which eliminates the need for intermediaries Thus, grain growers can operate and sell their products based on bidding processes beyond their local market. Buyers and sellers register for free, bargain anonymously, with broker fees being reduced (https:/ / farmlead.com/, accessed on 19 April 2020) (e-Marketplace Business model).

Full Harvest: This is the first B2B marketplace for ugly and surplus produce. With 20 billion pounds of "ugly" products lost in the US every year, Full Harvest creates a B2B marketplace to bring in communication growers with food companies to get rid of surpluses or defective products, thus reducing the waste. Full Harvest's awarded Marketplace allows farmers and shoppers to make deals, identify the involved parties, and reduce the time-consuming search and bargaining through the activation of trusted trading networks. (https:/ / www.fullharvest.com/, accessed on 19 April 2020) (B2B Marketplace Business model).

Farmers Edge develops data-driven technologies that enable farmers to efficiently operate and upgrade their production. This start-up uses disruptive technologies, satellite imagery and precision technology to provide farmers with the tools to identify, map, and manage farmland variability. Thus, using hardware and software technology concentrating on specific needs of agriculture enables the farmers to fulfill their tasks more efficiently (https:/ / www.farmersedge.ca/harvest/, accessed on 19 April 2020) (Data-driven business model, SaaS model).

The above start-ups demonstrate the basic set of services found in the online start-ups of the industry. They include on their websites data collection and analysis capabilities, chatbots, blogs, cloud services, SaaS (Software as a Service), mapping and company value analysis. These innovative e-business models were selected to further explore their assets in the AgriFood sector.

Thus, the companies initially offer shared e-business services that serve as benchmarks for the e-business model for competitors and new entrants. FarmLead allows users to quote, create and search for grain quotes. Users can view the offers on the website list in real time $24 \mathrm{~h}$ a day. It also uses chatbot to facilitate the user who logs in to the online market. Similar is the case with Full Harvest, which offers the user an online market for surplus or incomplete products. FarmersEdge uses cloud technology to store data collected by its sophisticated algorithms, but also provides the user with useful tools to monitor their farmland, generate real-time reports, and provide high-quality search information [26]. FoodLogiQ and Farmers Business Network use virtual value chains through cloud and without cloud technology, and additionally their mobile applications. Another concern is the company performance resulting from the reactions of customers to changes. The financial outcomes of the subscription model have performed well for Farmers Business Network, Farmers Edge and FoodLogiQ. Finally, the analysis of these models explores all the provided services and performance indicators to measure the digital transformation readiness and the competitiveness in the AgriFood-Tech landscape [27,28]. 


\subsection{Business Model Canvas (BMC) Framework}

The existing literature and research on business models has evolved significantly in the last years and the concept is now focusing on the context of digital technologies, value proposition and partnerships management [29-31].

There are several attempts a to represent a business model using several criteria and frameworks. A business model expresses the business logic of the company by positioning it in the value chain and the relevant market and technology drivers implemented. The eBusiness Model approach proposed in this paper pertains to the architecture of a company and its customers' and partners' network for creating, communicating and delivering value to one or several segments of customers in order to generate profitable and sustainable revenue streams. A sustainable business model is the one that is flexible enough to unfold new innovations based on technology alternatives.

The most popular framework was proposed by Osterwalder and Pigneur in the form of a "Business Model Canvas" (BMC) promoted via the strategyzer.com (accessed on 19 April 2020) portal [1,2]. Canvas Framework is a tool that fosters understanding, analysis, creativity, and designing of business models. Moreover, it presents a road map for digital transformation and sustainability providing valuable insights into what makes (or not) the model innovative, unique, and competitive. It represents the nine following modules that build the main business parts:

1. The customer segments block describes the segments of customers a company wants to offer value.

2. The value propositions block gives an overall view of a company's bundle of products and services; values may be quantitative (e.g., price, speed of service) or qualitative (e.g., design, customer experience). Additionally innovation (technology related), performance, customization, accessibility, cost and risk reduction, and convenience/usability issues could be included.

3. The communication, distribution and sales channels block refer to different touchpoints with the customers.

4. The customer relationships block explains the established and maintained relationships with each customer segment.

5. The revenue streams block describes the revenue flows of a company.

6. The key resources block outlines the most important assets required to make a model work.

7. The key activities block consists of the most important things a company must do to make its business model operate.

8. The key partnerships block refers to the network of suppliers and partners required to optimize the business model, acquire resources and reduce risk.

9. The cost structure block accumulates all cost incurred to make the model operational.

\section{Results}

Innovative AgriFood-Tech models enable new ways to deliver customer value using innovative digital technologies. e-Business models are defined as the conceptual instruments that signify the business logic and value proposition of companies in the digital environment.

\subsection{BMC Analysis of the AgriFood-Tech Models}

In this section, five AgriFood-Tech e-business models are analyzed based on the Canvas Framework to identify the interacting components that create and deliver value. The results of this analysis highlight the upcoming innovative business models that use digital technology as a sustainable and scalable resource in the AgriFood sector. Therefore, the expected outcome is to develop channels of interaction between customers and companies, between producers and consumers, and create new forms of trade or commercial transactions. The data in Table 1 were collected by an online analysis of all five companies' websites to define the various features available to the user. Then, business reports, elec- 
tronic articles and further research papers were used to analyze technical data and their financial performance.

Table 1. Available features on five companies' websites.

\begin{tabular}{|c|c|c|c|c|c|}
\hline & FoodLogiQ & $\begin{array}{c}\text { Farmers Business } \\
\text { Network }\end{array}$ & FarmLead & Full Harvest & Farmers Edge \\
\hline $\begin{array}{c}\text { Value } \\
\text { Proposition }\end{array}$ & $\begin{array}{l}\text { Innovation: } \\
\text { Cloud platform } \\
\text { FoodLogiQ Connect, } \\
\text { traceability } \\
\text { technology, } \\
\text { blockchain pilot; } \\
\text { Reduce recall costs } \\
\text { by using data to } \\
\text { track a supply chain. } \\
\text { Usability and } \\
\text { Performance } \\
\text { Ensure their } \\
\text { products are safe to } \\
\text { consume, } \\
\text { sustainability; } \\
\text { Scorecards; Mobile } \\
\text { app -FoodLogiQ } \\
\text { Connect. }\end{array}$ & $\begin{array}{c}\text { Innovation: } \\
\text { A network of more } \\
\text { than } 6500 \text { farms that } \\
\text { pay to access its } \\
\text { database of seed } \\
\text { prices, yields and } \\
\text { marketing } \\
\text { information; } \\
\text { Agronomic } \\
\text { Intelligence } \\
\text { technology, FBN } \\
\text { Analytics and Price } \\
\text { Transparency. } \\
\text { Usability and } \\
\text { Performance } \\
\text { Mobile app: FBN on } \\
\text { iOS and Android, } \\
\text { FBN Finance. With a } \\
\text { low-hassle } \\
\text { application process, } \\
\text { qualified farmers } \\
\text { can receive loan } \\
\text { financing approval } \\
\text { in as little as } 48 \text { h; } \\
\text { FBN Seed Finder } \\
\text { access to the largest } \\
\text { seed performance } \\
\text { database in } \\
\text { agriculture. }\end{array}$ & $\begin{array}{l}\text { Innovation: } \\
\text { Facilitates greater } \\
\text { equality, efficiency, } \\
\text { and transparency in } \\
\text { grain marketing; } \\
\text { Use of tools: Grain } \\
\text { Converter and } \\
\text { Grain Test; } \\
\text { FarmLead is an } \\
\text { online grain } \\
\text { marketplace that } \\
\text { allows buyers and } \\
\text { sellers to list, } \\
\text { negotiate and } \\
\text { finalize grain deals. } \\
\text { Usability and } \\
\text { Performance } \\
\text { This online grain } \\
\text { marketplace allows } \\
\text { farmers to find more } \\
\text { buyers and identify } \\
\text { the best possible } \\
\text { deal; Mobile app: } \\
\text { The Farmlead } \\
\text { Marketplace is } \\
\text { available as an app } \\
\text { for iOS and Android } \\
\text { for postings and } \\
\text { negotiations. }\end{array}$ & $\begin{array}{l}\text { Innovation: } \\
\text { Empowers } \\
\text { sustainability at the } \\
\text { root level with the } \\
\text { marketplace for } \\
\text { surplus and } \\
\text { imperfect produce; } \\
\text { Full Harvest } \\
\text { Technologies. } \\
\text { Usability and } \\
\text { Performance } \\
\text { The new Full } \\
\text { Harvest website: } \\
\text { new design } \\
\text { aesthetic, ease of } \\
\text { use of the platform; } \\
\text { Working with major } \\
\text { food and beverage } \\
\text { companies. }\end{array}$ & $\begin{array}{l}\text { Innovation: } \\
\text { Farm Command, } \\
\text { Smart VR and } \\
\text { Smart Nutrient } \\
\text { software; } \\
\text { Big Data analysis } \\
\text { Empowering } \\
\text { growers and ag } \\
\text { professionals with } \\
\text { data-driven } \\
\text { solutions; } \\
\text { list of managers to } \\
\text { help run a farm. } \\
\text { Usability and } \\
\text { Performance } \\
\text { Mobile app-eScout, } \\
\text { FarmCommand- } \\
\text { Scouting Manager, } \\
\text { cloud Growers' and } \\
\text { partners' solutions; } \\
\text { Added value for } \\
\text { farm data, risk } \\
\text { management and } \\
\text { profitability } \\
\text { maximization. }\end{array}$ \\
\hline $\begin{array}{l}\text { Customer } \\
\text { Relation- } \\
\text { ships }\end{array}$ & $\begin{array}{l}\text { Customization } \\
\text { Login/signup; } \\
\text { Search; } \\
\text { Communication } \\
\text { Blog, forum, } \\
\text { newsletter, mobile } \\
\text { app, notifications, } \\
\text { demographics, } \\
\text { analytics, webinars. }\end{array}$ & $\begin{array}{l}\text { Customization } \\
\text { Login/signup; } \\
\text { Search, forum } \\
\text { personal advice and } \\
\text { notifications, data } \\
\text { analysis, } \\
\text { SMS/MMS. }\end{array}$ & $\begin{array}{l}\text { Customization } \\
\text { Login/signup; } \\
\text { Search, product list, } \\
\text { prices, buyers' and } \\
\text { producers' data, } \\
\text { Chatbot } 24 / 7 \text {. }\end{array}$ & $\begin{array}{l}\text { Customization } \\
\text { Login/signup; } \\
\text { Search, blog and } \\
\text { forum, newsletter, } \\
\text { mobile app, } \\
\text { notifications, } \\
\text { analytics. }\end{array}$ & $\begin{array}{l}\text { Customization } \\
\text { Login/signup; } \\
\text { Search; Blog, forum, } \\
\text { newsletter, mobile } \\
\text { app, notifications, } \\
\text { demographics, } \\
\text { analytics, demos, } \\
\text { webinars; } \\
\text { FarmCommand, a } \\
\text { customizable } \\
\text { dashboard. }\end{array}$ \\
\hline $\begin{array}{c}\text { Target } \\
\text { Customers }\end{array}$ & $\begin{array}{c}7000 \text { food } \\
\text { companies around } \\
\text { the world Food } \\
\text { distributors, food } \\
\text { importers, suppliers, } \\
\text { growers, farmer, } \\
\text { shippers, restaurant } \\
\text { managers; Tyson, } \\
\text { Subways, Whole } \\
\text { Food Markets, } \\
\text { Chipotle, Robinson } \\
\text { Fresh, Dave \& } \\
\text { Busters, etc. }\end{array}$ & $\begin{array}{l}\text { Growers, shippers, } \\
\text { distributors, } \\
\text { partners, sellers; } \\
\text { Traders. }\end{array}$ & $\begin{array}{l}\text { Buyers, sellers, } \\
\text { growers, traders, } \\
\text { distributors, } \\
\text { producers, partners; } \\
\text { FarmLead offers } \\
\text { buyers' access to an } \\
\text { unparalleled pool of } \\
\text { sellers and an easy } \\
\text { way to view and } \\
\text { negotiate on offers. }\end{array}$ & $\begin{array}{l}\text { Buyers, sellers, } \\
\text { growers, traders, } \\
\text { distributors, } \\
\text { producers, partners. }\end{array}$ & $\begin{array}{l}\text { Buyers, sellers, } \\
\text { growers, traders, } \\
\text { distributors, } \\
\text { producers, partners, } \\
\text { suppliers. }\end{array}$ \\
\hline
\end{tabular}


Table 1. Cont.

\begin{tabular}{|c|c|c|c|c|c|}
\hline & FoodLogiQ & $\begin{array}{c}\text { Farmers Business } \\
\text { Network }\end{array}$ & FarmLead & Full Harvest & Farmers Edge \\
\hline $\begin{array}{l}\text { Distribution } \\
\text { Channels }\end{array}$ & $\begin{array}{c}\text { Online transactions; } \\
\text { Online service } \\
\text { providing. }\end{array}$ & $\begin{array}{l}\text { Online transactions; } \\
\text { Online service } \\
\text { providing. }\end{array}$ & $\begin{array}{l}\text { Online transactions; } \\
\text { Online service } \\
\text { providing. }\end{array}$ & $\begin{array}{c}\text { Online transactions; } \\
\text { Online service } \\
\text { providing. }\end{array}$ & $\begin{array}{c}\text { Online transactions; } \\
\text { Online service } \\
\text { providing. }\end{array}$ \\
\hline Partnerships & $\begin{array}{c}\text { Leading food } \\
\text { companies are } \\
\text { partnering with } \\
\text { FoodLogiQ: } \\
\text { WorldSync, World } \\
\text { Quality Services, } \\
\text { NRA (National } \\
\text { Restaurant } \\
\text { Association), Savor, } \\
\text { PMA. }\end{array}$ & $\begin{array}{c}\text { Acquisition of } \\
\text { resources and } \\
\text { activities: } \\
\text { Collaboration with } \\
\text { Double Bottom Line } \\
\text { and FarmSource Ag } \\
\text { LLC. }\end{array}$ & $\begin{array}{l}\text { Acquisition of } \\
\text { resources and } \\
\text { activities: } \\
\text { Collaboration with } \\
\text { experts' labs. }\end{array}$ & $\begin{array}{l}\text { Acquisition of } \\
\text { resources and } \\
\text { activities. }\end{array}$ & $\begin{array}{c}\text { Acquisition of } \\
\text { resources and } \\
\text { activities: Partners } \\
\text { Allied Cooperative, } \\
\text { Trotter Fertilizer, } \\
\text { Davis Instruments, } \\
\text { Moody's. }\end{array}$ \\
\hline $\begin{array}{l}\text { Revenue } \\
\text { Streams }\end{array}$ & $\begin{array}{l}\text { Customers' } \\
\text { subscriptions, } \\
\text { Partners' } \\
\text { advertising. }\end{array}$ & $\begin{array}{l}\text { Subscription fees, } \\
\text { memberships. }\end{array}$ & $\begin{array}{l}\text { When a deal is } \\
\text { reached there is a } \\
\text { fee charged. } \\
\text { The connection fee } \\
\text { of } 1 \text { cent per bushel } \\
\text { traded } \\
\text { is paid to FarmLead } \\
\text { by both the Buyer } \\
\text { and the Seller. }\end{array}$ & $\begin{array}{l}\text { Revenue from this } \\
\text { site is based on the } \\
\text { commission rate for } \\
\text { each transaction. }\end{array}$ & Subscription fees. \\
\hline $\begin{array}{l}\text { Cost } \\
\text { structure }\end{array}$ & $\begin{array}{c}\text { Platform } \\
\text { development and } \\
\text { management. }\end{array}$ & $\begin{array}{c}\text { Platform } \\
\text { development and } \\
\text { management. }\end{array}$ & $\begin{array}{c}\text { Platform } \\
\text { development and } \\
\text { management. }\end{array}$ & $\begin{array}{c}\text { Platform } \\
\text { development and } \\
\text { management. }\end{array}$ & $\begin{array}{c}\text { Platform } \\
\text { development and } \\
\text { management. }\end{array}$ \\
\hline
\end{tabular}

Data collected from: www.foodlogiq.com; www.fbn.com; www.farmlead.com; www.fullharvest.com; www.farmersedge.com, (accessed on 12 November 2020).

\subsection{Value Proposition-Innovation}

FoodLogiQ technology allows traceability along the entire supply chain through the use of FoodLogiQ Connect, a cloud platform that unlocks the enormous value between food companies' supply chains. Some of the functions are product recall, control management, compliance and regulation, supplier management, sustainability, safety and product quality. FoodLogiQ is taking the lead with blockchain exploration aiming to reduce food recall costs [32].

Farmers Business Network's innovative Agronomic Intelligence program helps the user to access the most advanced analytical data of agriculture, involving technical intelligence algorithms and large volumes of data. By means of FBN Analytics technology, it provides services such as selecting the best seeds for the soil, evaluation, mapping and performance analysis. Price Transparency facilitates negotiation with suppliers in that the user can see what other farmers really pay for the same products.

FarmLead has created a new core trading feature that allows buyers and sellers to trade grain through deals and contracts. The particular tool is the Grain converter and the GrainTest, an easy and innovative way to test grain samples.

Full Harvest uses its online platform to sell or buy products that are in surplus or ugly.

Finally, with Farmers Edge, the user can log in to FarmCommand, which is a customizable toolbar that presents a summary of the farm. The user can then access a variety of tools referred to as administrators. It also provides Smart VR and Smart Nutrient software that analyze large volumes of data. 


\subsection{Value Proposition-Usability and Performance}

FoodLogiQ has launched a mobile application aimed at users of Android and IOS software. The website provides real-time food supply chain virtualization software and gathers all the data necessary for a transparent supply chain compatible with the Food Safety Modernization Act (FSMA) for the Food and Drug Administration (FDA). With the user-friendliness of the software, the user can use simple steps to use scorecards and vendor scores to highlight the top, while simultaneously viewing and editing files and workflows of Corrective Action System (CAPA) and HACCP food safety plans.

The FarmLead mobile app is user-friendly. The design of the graphical interface (UI Design) is useful, containing data and information about cereals and search lists with sales prices for each seller's product. The FarmLead website provides a chatbot service for instant customer service.

The Farmers Business Network has a mobile application aimed only at IOS software users. The FBN OPS application allows the user to collaborate with his/her team and monitor business data. It also provides the service of direct communication with consultants and workers for a complete picture of the operation of the farm. The website of both Farmers Business Network and Full Harvest have the ability to login (login/signup) and blog communication, improving the overall experience of the site for users.

Finally, Farmers Edge provides two mobile applications for Android and iOS mobile users. The innovative eScout app provides agricultural professionals with an advanced platform equipped with tools to monitor and deal with environmental conditions, generate real-time reports and provide users with high-quality information. eScout has a userfriendly interface that is easy to use and navigate. It is designed to be a simple solution. The second application is FarmCommand Scouting Manager which is a new tool based on applications that can be used either without internet connection or through direct connection to the cloud. With this tool, growers and agronomists can use historical data to navigate specific areas that present diversity or problems and easily record observations, take photos and share data with their team.

\subsection{Customer Relationships-Customization}

FoodLogiQ as a Software as a Service (SaaS), but also as a mobile application with FoodLogiQ Connect technology provides the user with the ability to customize the entire graphical user interface (UI) through the "customization" option. Some features of this option are not provided for free and belong to the Premium user category at a higher cost. Adjustments can be made to reports, the creation of custom bar graphs, pie graphs and heat maps for data extraction [33].

FarmLead, Farmers Business Network and Farmers Edge have mobile applications with different uses. The FarmLead mobile app shows grain sales prices, producer estimates, transaction history, sales lists, and photos. Users can easily make a transaction according to their requirements. The Farmers Edge application allows interaction between users, agronomists and employees, having the ability to customize the application according to the intended use at the time. The Farmers Business Network uses similar technology in its application for IOS. Both applications focus on company data, while in the first application users can customize the graphic about the products to display their listings.

FarmLead.com (accessed on 19 April 2020) implements a visual communication, using chatbot. FarmerEdge and FoodLogiQ have a sleek design but the design of Full Harvest is simpler and more intuitive. The user can easily connect and influence with other users, including company's consultants, through the blog and the communication forum.

\subsection{Target Customers}

The target customers of the companies include buyers, sellers, growers, traders, agronomists, food distributors, food importers, middlemen and suppliers. 


\subsection{Channels}

Companies' webpages facilitate customers' communication and the opportunity to reach customer segments offering sales opportunities, advertising, blogs/forums and newsletters with specific references to the business. The companies enable online transactions and online service providing.

\subsection{Customer Relationships}

When it comes to personal services, FoodLogiQ builds relationships with buyers and sellers who advertise indirectly on their website. By comparison, the rest of the companies build relationships with the same customer segments, including users, buyers and sellers through communication blogs or through a forum and other features such as FarmLead chatbot. Moreover, users can access customized services on all companies' websites [5,34].

\subsection{Partnerships}

All the business models create and offer value propositions through their connection to networks [35]. FarmLead and Full Harvest bring buyers and sellers or sellers with sellers in contact, in return of the commissions that the company shares. FoodLogiQ offers access to a large (and growing) global suppliers' network of partners offering control services to label companies, producers' associations and more. Some of its partners are WorldSync, World Quality Services, National Restaurant Association (NRA), Savor, PMA. In addition, FoodLogiQ works with many giants in the AgriFood industry, which it advertises on its website (Subway, Buffalo Wild).

FarmLead does not handle, sell or buy grain. The market is traded directly between the buyer and the seller; they are just intermediaries. All operations of the company are performed by the company staff (marketing departments, customer department, IT department). Its only collaboration is to control the grain sample through independent specialized laboratories located throughout North America, British Columbia, Alberta, Saskatchewan, Manitoba, Ontario and Quebec.

The Farmers Business Network has partnered with Double Bottom Line, a company that invests in companies that can deliver top venture capital returns and deliver social, environmental and economic benefits. It provides an online wallet advertising the partner companies in which the Farmers Business Network is located. He also works with FarmSource Ag LLC, a law firm that provides agronomic advice to growers. With this agreement, FarmSource Ag customers have lower cost access to the FBN network.

Farmers Edge has announced a partnership with Great Plains Precision Ag, Inc. (GPPA), one of the leading suppliers of precision agricultural services in the USA. In addition, it has a partnership with Allied Cooperative, a leading provider of agronomy, feed, cereals and grower equipment in 700,000 acres in central and western Wisconsin. More than 2200 Allied customers have access to the wide range of Farmers Edge products and services. It has a similar partnership with Trotter Fertilizer, Nebraska's leading retailer of NutriSphere-N Nitrogen Management Solutions and AVAIL Phosphorus Pharmaceutical Enhancers. Through this partnership, the Trotter Fertilizer provides growers with advanced precision farming recommendations from Farmers Edge to enhance existing VRT (Variable Rate Technology) programs for their customers throughout central Nebraska. Finally, the company is partnering with Moody's to expand Ag Precision technology throughout Western Canada.

\subsection{Revenue Streams}

FoodLogiQ and Farmers Edge use the SaaS business model. SaaS is not a profitable business model on its own. SaaS only becomes profitable when combined with a strategic revenue model. One of the biggest sources of input for the SaaS model is subscription. Although it is not the only source of revenue for the model, we see that it is used by both companies. FoodLogiQ uses packages with annual subscriptions depending on the services that the customer intends to use. The charge depends on the area that should 
be covered with the software and services, as well as the number of suppliers of the user. The company also uses the Data-Driven Business Model, providing comprehensive services such as allowing food safety professionals to monitor the product from start to finish, ensuring that standards are always met. FoodLogiQ also allows customers to share data, whether it is critical tracking data for traceability of the entire production process or data related to their suppliers. Finally, FoodLogiQ allows customers to detect supply chain abnormalities, complete business monitoring, and improve point anxiety trends by controlling statistical procedures.

Farmers Edge, with the combination of the SaaS model, a subscription model, but also a data model, offers different pricing packages to its customers and thus secures revenue for the company. Farmers Edge guarantees advanced agricultural solutions to promote profitability with a proven track record in agricultural precision. The company has scientific tools for locating and mapping field variability. Thus, it optimizes crop inputs, having higher yields, better quality and less environmental impact.

Farmers Business Network does not use the SaaS business model but uses a subscription business model along with the data model. The reason why the company is not included in the services of the SaaS model is because it does not offer cloud service. The company offers one-year subscription that costs USD 600, a two-year subscription to USD 1100 and a five-year subscription that costs USD 2500. By purchasing the software, the user can receive a number of services: use of the Seed Finder, Farmers Business Network benchmarking for performance, weather analysis, price transparency, free admission to Farmer2Farmer and other network events, precision maps for soil, yield, fertility, and planting. The user also obtains access to annual farm surveys and use of the mobile application FBN Ops, Seed Finder and Prices.

\subsection{Cost Stucture}

The primary cost refers to the construction and management of the business platform. This includes hardware and systems infrastructure, such as web servers, chatbots, artificial and business intelligence systems, and customer relationship management software.

\section{Discussion}

\subsection{AgriFood-Tech Paradigms' Expected Benefits and Challenges}

The analysis of the components of a model can lead to useful conclusions about the effectiveness of the modern technology it uses as well as the possibility of upgrading it for better customer service and increased efficiency. In this study, five innovative ebusiness models were explored: FoodLogiQ, Farmers Business Network, Farmlead, Full Harvest and Farmers Edge have been analyzed using the BCM framework, including modules, such as value proposition, customers segments of each company, customer relationships, communication and distribution channels, key partnerships, activities and resources, cost structure and revenue streams. These are some of the most innovative and disruptive companies in the world that are moving towards a more secure and sustainable agricultural future.

Target customers are similar in all companies as they mostly pertain to buyers, sellers, growers, agronomists, distributors, and intermediaries. Only FoodLogiQ is aimed at more specific customer groups such as food distributors, food importers, shippers, and restaurants. Taking into consideration the provided services of the companies, FoodLogiQ and Farmers Edge have SaaS (Software as a Service) and subscription features. The Farmers Business Network does not offer cloud services and belongs to the type of business subscription model. It is worth noting that all the companies use modern business models, incorporating a DD business model. Thus, they store a large amount of information which they evaluate through "smart" algorithms but also business intelligence, extracting reliable and useful insight for their customers. Full Harvest and Farm Lead companies use a similar business model to Rappa's Brokerage Model, the Marketplace Exchange model. The innovation feature of the value proposition and the technology they apply constitute 
their disruptive features leading to digital transformation scenarios. For example, the FoodLogiQ Connect innovative service using blockchain technology enables the user to extend supply chain traceability by adding operations such as product recall, control management, compliance and regulation, and quality management events. The traditional execution of the above is time consuming and inconvenient as growers are faced with a large amount of data and human errors. This delays the purchase and sale of products, reduces productivity, and revenues. Ensuring product quality and safety, meeting customer needs and differentiating from the competition requires the effective coordination of all stakeholders regarding goods, services, information and knowledge flows [36].

Similarly, Farmers Edge provides farm management and data analysis through Smart VR and Smart Nutrient software. Moreover, the Farmers Business Network using FBN Analytics and Price Transparency tools has increased customer value proposition by providing online product reviews. The revenue streams and the increased profitability of FoodLogiQ and Farmers Edge, the high-volume software-driven subscription service and the online advertising of their associates add value to the models. Partnerships, popularity, and success seem to be correlated as FoodLogiQ and Farmers Edge have the most partners, thus providing access to more customers. All companies except Full Harvest use mobile application technology, thus improving customers' experience. Digital platforms, the mobile one in particular, have positively impacted many areas of the AgriFood sector in developing regions. According to Joiner, "there is growing potential for these platforms to disrupt the agriculture supply value chain in these regions as investors build on the rising adoption of mobile internet and digital payment solutions by end consumers and farmers to develop new go-to market models for agriculture produce. This could have a significant impact on the agricultural sector in developing regions" [37]. An important factor in creating value for customers is easy access to information and services related to their transactions. Companies that combine the Data-Driven business model with characteristics of any other business model have a better financial position with higher percentages in their annual revenue [23]. The BMC framework, due to the level of detail it offers, allows a comprehensive analysis focusing on innovation and customization features [38]. As the AgriFood sector experiences difficulties, the information of this analysis could help companies to adapt to new environmental changes and conditions invest in in new technologies for a faster recover of the AgriFood industry. So, Annosi et al. [39] depict six examples of food companies that have implemented a circular business model using the Triple Layer Business Model Canvas.

As Tim O'Reilly says, "there's not a single business model, and there's not a single type of electronic content. There are really a lot of opportunities and a lot of options and we just have to discover all of them" [40].

\subsection{Disruptive Technology Drivers and Implications in AgriFood Industry}

AgriFood-Tech is an ecosystem that includes all the AgriFood involved parties such as farmers, brokers, technical supporters, financial institutions, agronomists, food organizations, start-ups and customers, acting as buyers, sellers and partners and using disruptive technologies on innovative processes within the entire AgriFood chain. In this section, we present several technology drivers and their implications in the AgriFood industry towards digital transformation resulting from the analysis of the five AgriFood-Tech paradigms (Figure 1).

These technology drivers refer to Big Data, Data Analytics-Artificial Intelligence (AI) techniques and Machine learning, Information and Knowledge systems including data gathering, sharing and analytics tools, "smart farm" technology for the farming operations applying smart devices, sensors, IoT and robotics, cloud services (SaaS, Daas, Xaas), mobile apps, e-Marketplace platforms and further e-Commerce techniques, and blockchain [41-49]. Each of the above technologies operating in digital environment bring their users closer to digital transformation providing substantial implications in the AgriFood operations [50]. 


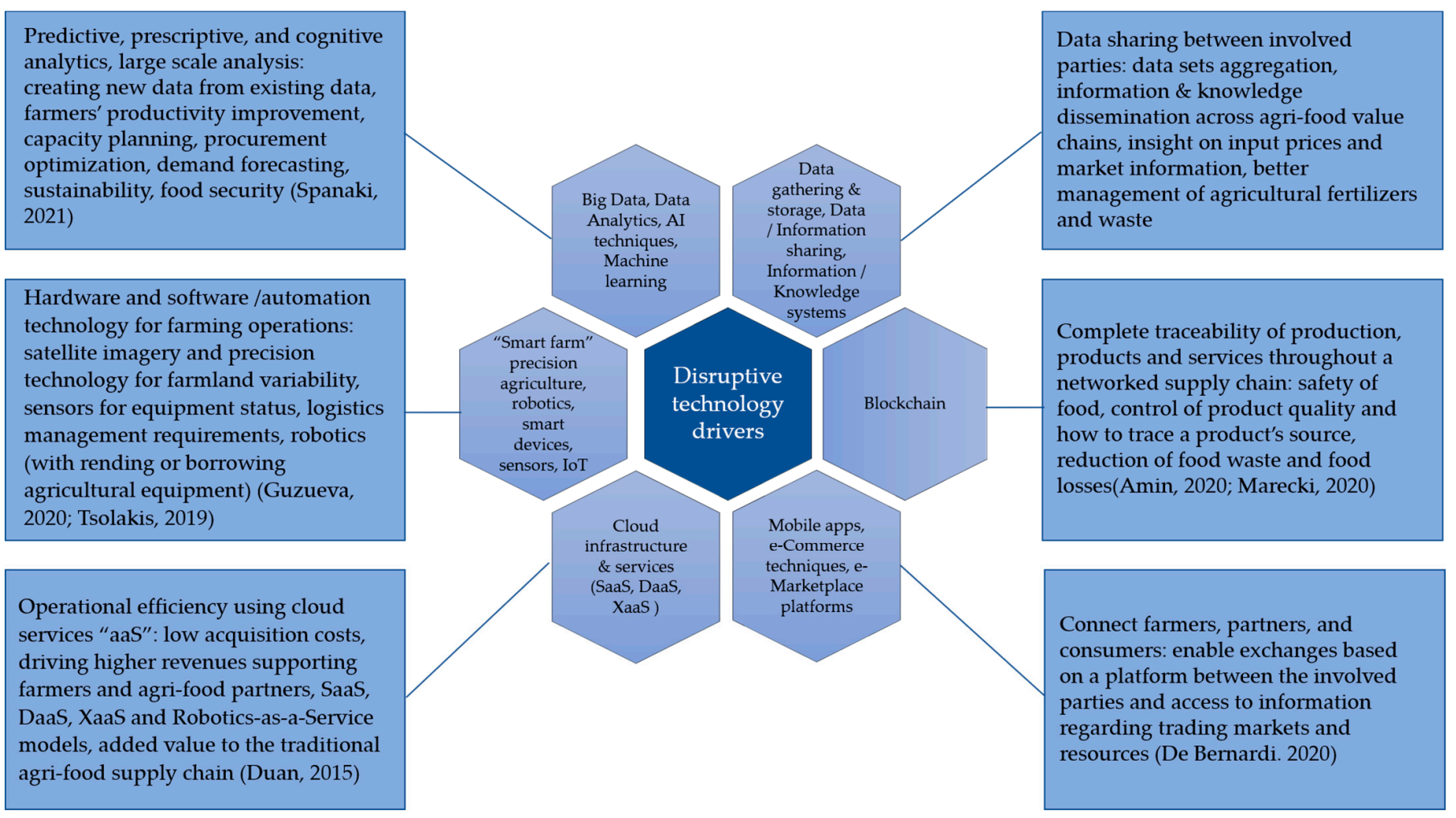

Figure 1. Disruptive technology drivers and implications in AgriFood industry towards digital transformation.

\subsection{SWOT Analysis of AgriFood-Tech Models}

In Table 2, we present the outcoming results leading to implications of the AgriFoodTech models in the AgriFood sector clarifying strengths, weaknesses, opportunities and threats related to the models observed [3]. Thus, we can consider the expected benefits and obstacles of using similar Tech e-business models exploring the trends of the AgriFood ecosystem [51]. There is a need to improve the food quality and security due to the growing food requirements based on the growing population and due to the demand for more healthy and environmentally friendly products.

FoodLogiQ develops a supply chain transparency software designed to validate supplier compliance with food safety. The FoodLogiQ Connect platform includes over 2000 registered businesses in over 35 countries with 18,000 locations. According to this model, supply chain integration and traceability, recall management and food safety compliance (via advanced analytics and blockchain technology) are achieved [49]. It enables involved parties (restaurants, food traders, and other food companies) to have end-to-end traceability while supporting safe and high-quality food products across the supply chain, resulting in the management of an online supplier community. With lot-level traceability, food companies see exactly where the product is at any time, especially when it matters most during an investigation.

FBN provides real-time environmental monitoring solutions for grain and food production, storage and transport using IoT technology to help farmers maximize their profit potential. Thus, according to this model data-driven tools and advanced analytics and predictive algorithms enhance transparent insights redefining value for the participants via subscription. Data are automated collected, wirelessly uploaded and analyzed. The system enables farmers to monitor the environmental conditions in real time, hence improving their operational efficiency, eliminating human error, and increasing their profitability [43,50].

FarmLead connects grain growers directly with businesses. This model helps farmers at one end get better prices and deal with consistent demand and on another end, it helps retailers to source agriproducts directly from farmers. Thus, using an e-marketplace platform the two parties of the exchange communicate and collaborate effectively at a 
lower cost, better speed, and larger scale. Prerequisites for the adoption of this model is the cost of the participation/subscription and the trust regarding the new way to do business.

Table 2. SWOT Analysis of five AgriFood-Tech models.

\begin{tabular}{|c|c|c|c|c|}
\hline $\begin{array}{l}\text { AgriFood-Tech Models } \\
\text { and Paradigms }\end{array}$ & Strengths & Weaknesses & Opportunities & Threats \\
\hline $\begin{array}{c}\text { Supply Chain Integration, } \\
\text { Data-Driven, Data } \\
\text { Analytics, SaaS business } \\
\text { model } \\
\text { (FoodLogiQ) }\end{array}$ & $\begin{array}{l}\text { Supply chain } \\
\text { traceability, Food quality } \\
\text { and safety }\end{array}$ & $\begin{array}{c}\text { Lack of trust between involved } \\
\text { parties, Cost issues }\end{array}$ & $\begin{array}{c}\text { Blockchain potential, } \\
\text { AI as enabler to cut food } \\
\text { waste and make nutritious } \\
\text { food more accessible using } \\
\text { predictive data systems, } \\
\text { Partnerships' growth (list } \\
\text { of brands pursuing food } \\
\text { supply chain transparency) }\end{array}$ & $\begin{array}{c}\text { New entrants } \\
\text { FoodTech } \\
\text { start-ups with } \\
\text { disruptive applicable } \\
\text { technology along the } \\
\text { value chain after the } \\
\text { farm gates } \\
\text { including supply } \\
\text { chain, food processing, } \\
\text { food safety and waste }\end{array}$ \\
\hline $\begin{array}{l}\text { Big Data, Subscription, } \\
\text { Data-Driven model, } \\
\text { business model } \\
\text { (Farmer's Business } \\
\text { Network FBN) }\end{array}$ & $\begin{array}{l}\text { Software Hardware and } \\
\text { farm management } \\
\text { Data/Farm } \\
\text { Management } \\
\text { (Data Analytics and AI) }\end{array}$ & $\begin{array}{c}\text { Lack of Internet infrastructure } \\
\text { and digital literacy of the } \\
\text { farmers, } \\
\text { difficulties of farm automation } \\
\text { and robotics to bring about } \\
\text { high performance, } \\
\text { farmers are reluctant to apply } \\
\text { new technologies, } \\
\text { Fear/lack of trust to give } \\
\text { access to their data }\end{array}$ & $\begin{array}{l}\text { Make machines with the } \\
\text { use of sensors, IoT and } \\
\text { robotics more competitive } \\
\text { with human work, More } \\
\text { sophisticated automation } \\
\text { solutions, } \\
\text { Improvement of agri } \\
\text { production and quality, } \\
\text { Support of open data } \\
\text { initiatives in rural areas }\end{array}$ & $\begin{array}{c}\text { Small-farmers' } \\
\text { hesitation and fear to } \\
\text { change, } \\
\text { Who will have the } \\
\text { governance of the } \\
\text { model? } \\
\text { Lack of trust between } \\
\text { farmers and start-ups }\end{array}$ \\
\hline $\begin{array}{l}\text { e-Marketplace business } \\
\text { model } \\
\text { (FarmLead) }\end{array}$ & $\begin{array}{l}\text { Trade enhancement, } \\
\text { Local farmers can } \\
\text { expand beyond their } \\
\text { local markets }\end{array}$ & $\begin{array}{c}\text { Financing difficulties, } \\
\text { Lack of trust to change the } \\
\text { way of traditional working }\end{array}$ & $\begin{array}{l}\text { Start-ups gain credibility } \\
\text { with local farmers and } \\
\text { accelerate their } \\
\text { participation, } \\
\text { Complete farm cycle } \\
\text { management }\end{array}$ & $\begin{array}{l}\text { Lack of trust for the } \\
\text { new entrants }\end{array}$ \\
\hline $\begin{array}{c}\text { B2B e-Marketplace business } \\
\text { model, Data Analytics and } \\
\text { AI } \\
\text { (Full Harvest) }\end{array}$ & $\begin{array}{c}\text { Environmental impact } \\
\text { and } \\
\text { waste reduce, } \\
\text { e-Commerce networks } \\
\text { and value chain position } \\
\text { in retail and trade }\end{array}$ & $\begin{array}{l}\text { Improvement of the } \\
\text { sustainability concept towards } \\
\text { zero-waste }\end{array}$ & $\begin{array}{l}\text { Development of a digital } \\
\text { customer experience, } \\
\text { Creation of a more } \\
\text { sustainable and effective } \\
\text { food platform }\end{array}$ & $\begin{array}{l}\text { Lack of worldwide } \\
\text { regulations for food } \\
\text { processing and } \\
\text { novel ingredients }\end{array}$ \\
\hline $\begin{array}{l}\text { Data-driven, SaaS business } \\
\text { model, Big Data Analytics, } \\
\text { (Farmers Edge } \\
\text { Laboratories) }\end{array}$ & $\begin{array}{l}\text { Help farmers feed the } \\
\text { world in a sustainable } \\
\text { way (software, sensors, } \\
\text { IoT, robotics, mobile } \\
\text { apps and automation) }\end{array}$ & $\begin{array}{c}\text { Precision } \\
\text { farming, } \\
\text { Support farming communities } \\
\text { providing education and } \\
\text { learning opportunities related } \\
\text { to the innovative technologies }\end{array}$ & $\begin{array}{l}\text { Political constraints to } \\
\text { build a standardized } \\
\text { infrastructure for sharing } \\
\text { agri-data }\end{array}$ & $\begin{array}{l}\text { Fragmented initiatives } \\
\text { in rural areas } \\
\text { constitute bad practice } \\
\text { examples }\end{array}$ \\
\hline
\end{tabular}

Full Harvest is an online marketplace with a focus on sustainability. Full Harvest has developed a marketplace for surplus and imperfect produce. It helps growers get the most out of a harvest and food companies save money by bringing farm excess to market. There is a B2B platform connecting large farms to food businesses to sell significantly discounted yet perfectly good surplus and imperfectly shaped produce that would have otherwise gone to waste. This model aims to solve this problem by bringing an additional revenue stream to farmers, lower the cost of healthy food production, while significantly reducing wasted food and resources. The challenge is a win-win for every involved entity.

Farmers Edge empowers the growers and ag-professionals by providing them with a complete solution that drives mobile adoption and further technological resources, software, and data insights. Mobile equipment will be used not only for accessing databases and clouds, but more and more for collection of data. Limited financial capacity of smallfarmers, lack of access to growth capital and funds, unfamiliarity of farmers with advanced technology combined with limited technological skills, inefficient trade marketplaces beyond their local areas and lack of transparency in value chains between the farmers and ultimate retailers are problems in the AgriFood industry that this model seeks to solve. 
All the above-mentioned models combine different disruptive technologies aiming to use technological innovation for food quality, safety and security, "smart farm" production and environmentally and socially sound production enhancing the customers' experience. Furthermore, the challenge is to gain a complete traceability of production, products and services throughout a networked value chain.

Moving AgriFood-Tech models toward digitalization in the AgriFood industry for long-term sustainability requires the continuous updating of ideas based on the analysis of previous activities of organizations, networks, and start-ups that demonstrate strengths and weaknesses of their implementation [52].

\section{Conclusions}

The rising demand for food due to emerging market population growth, the shift to higher value-added products, cost pressures and food safety regulation will lead to product expansion, higher standards, and a more intense focus on traceability supported by disruptive AgriFood-Tech models. Information has become part of the capital and business assets of AgriFood companies, shifting from information management to intelligent information activation. Digital innovators use technology assets-along with people, capital, and physical assets-to create new business models. Food supply chain innovation seems to be reactive to environmental forces, performance growth, and regulatory externalities, such as food quality guarantee through traceability, logistics optimization, waste treatment, and food safety compliance. The study clarifies the strengths and weaknesses of e-business models, allowing companies to improve performance and customer satisfaction. The limitation of this study is that it discusses several disruptive technologies pertaining to a small number of start-ups for their application in the AgriFood industry. As part of our future research, we consider the approach based on the triple layered business model canvas and distinguishing "FarmTech" inside the farmgate and "Food Supply Chain Tech" regarding the post-farm gate [53]. Further research regarding the use of these AgriFoodTech models may also address the impacts of the COVID-19 pandemic on the development and deployment of new models [54].

Author Contributions: Conceptualization and formal analysis: M.V. and C.Z.; investigation and methodology: M.V., K.V. and M.M.; writing—original draft preparation: M.V. and C.Z.; review and editing: M.V., C.Z., K.V. and M.M. All authors have read and agreed to the published version of the manuscript.

Funding: This research received no external funding.

Institutional Review Board Statement: Not applicable.

Informed Consent Statement: Not applicable.

Data Availability Statement: Not applicable.

Conflicts of Interest: The authors declare no conflict of interest.

\section{References}

1. Osterwalder, A. The Business Model Ontology a Proposition in a Design Science Approach. Ph.D. Thesis, Université de Lausanne, Faculté des Hautes études Commerciales, Lausanne, Switzerland, 2004.

2. Osterwalder, A.; Pigneur, Y.; Tucci, C.L. Clarifying Business Models: Origins, Present, and Future of the Concept. Commun. Assoc. Inf. Syst. 2005, 16, 1. [CrossRef]

3. Thrive Agrifood I Advancing AgTech \& FoodTech Innovation | 2020 THRIVE TOP 50 FOODTECH. Available online: https: //thriveagrifood.com/startups/thrive-top-50/ (accessed on 10 April 2021).

4. McGrath, M. The 25 Most Innovative AgTech Startups. 2018. Available online: https:/ /www.forbes.com/sites/maggiemcgrath/ 2018/06/27/the-25-most-innovative-agtech-startups-in-2018/ (accessed on 9 April 2021).

5. Matopoulos, A.; Vlachopoulou, M.; Manthou, V.; Manos, B. A Conceptual Framework for Supply Chain Collaboration: Empirical Evidence from the Agri-food Industry. Supply Chain Manag. Int. J. 2007, 12, 177-186. [CrossRef]

6. EU Project DIVA: Boosting Innovative Digitech Value Chains for Agrofood. Available online: https://www.projectdiva.eu/ (accessed on 23 April 2021). 
7. Farm Tech Market Map: Why It's Time to Distinguish Farm Tech from the Messy Supply Chain. Available online: https: / / agfundernews.com/farm-tech-market-map-why-its-time-to-distinguish-farm-tech-from-the-messy-supply-chain.html (accessed on 9 April 2021).

8. Zeng, Y.; Jia, F.; Wan, L.; Guo, H. E-Commerce in Agri-Food Sector: A Systematic Literature Review. Int. Food Agribus. Manag. Rev. 2017, 20, 439-459. [CrossRef]

9. Rappa, M. Business Models on the Web: Managing the Digital Enterprise; North Carolina State University: Raleigh, NC, USA, 2000.

10. Strzebicki, D. The Development of Electronic Commerce in Agribusiness-The Polish Example. Procedia Econ. Financ. 2015, 23, 1314-1320. [CrossRef]

11. Canavari, M.; Fritz, M.; Hofstede, G.J.; Matopoulos, A.; Vlachopoulou, M. The Role of Trust in the Transition from Traditional to Electronic B2B Relationships in Agri-Food Chains. Comput. Electron. Agric. 2010, 70, 321-327. [CrossRef]

12. Panetto, H.; Lezoche, M.; Hernandez, J.E.; Alemany Diaz, M.D.M.E.; Kacprzyk, J. Special Issue on Agri-Food 4.0 and Digitalization in Agriculture Supply Chains-New Directions, Challenges and Applications. Comput. Ind. 2020, 116, 103188. [CrossRef]

13. Rodrigues, T.C.; Leitão, F.O.; Thomé, K.M.; Cappellesso, G. Sharing Economy Practices in Agri-Food Settlements: Integration of Resources, Interdependence and Interdefinition. J. Clean. Prod. 2021, 294, 126357. [CrossRef]

14. Warrillow, J. The Automatic Customer: Creating a Subscription Business in Any Industry; Penguin: London, UK, 2015; ISBN 978-0-698-17633-1.

15. Nabradi, A.; Kovács, T. Types of Platform Based Collaborative Economy and Its Potential Areas in Agribusiness. West. Balk. J. Agric. Econ. Rural Dev. 2020, 2, 9-19. [CrossRef]

16. Bavec, S.; Bouroullec, M.D.M.; Raynaud, E. Analysis of Short Food Supply Chain Governances: Innovative Collective Platforms Supplying Local Produce. Available online: http:/ /ageconsearch.umn.edu/record/258169 (accessed on 9 April 2021).

17. Ward, J.S.; Barker, A. Undefined By Data: A Survey of Big Data Definitions. arXiv 2013. Available online: https://arxiv.org/pdf/ 1309.5821.pdf (accessed on 14 May 2021).

18. Joubert, A.; Murawski, M.; Bühler, J.; Bick, M. Happiness and Big Data-Theoretical Foundation and Empirical Insights for Africa. In Proceedings of the Responsible Design, Implementation and Use of Information and Communication Technology, Skukuza, South Africa, 6-8 April 2020; Hattingh, M., Matthee, M., Smuts, H., Pappas, I., Dwivedi, Y.K., Mäntymäki, M., Eds.; Springer International Publishing: Cham, The Switzerland, 2020; pp. 443-455.

19. Brownlow, J.; Zaki, M.; Neely, A.; Urmetzer, F. Data and Analytics-Data-Driven Business Models: A Blueprint for Innovation. Camb. Serv. Alliance 2015, 7, 1-17.

20. Singh, S.; Chana, I.; Buyya, R. Agri-Info: Cloud Based Autonomic System for Delivering Agriculture as a Service. Internet Things 2020, 9. [CrossRef]

21. Lezoche, M.; Hernandez, J.E.; Alemany Díaz, M.D.M.E.; Panetto, H.; Kacprzyk, J. Agri-Food 4.0: A Survey of the Supply Chains and Technologies for the Future Agriculture. Comput. Ind. 2020, 117, 103187. [CrossRef]

22. Digital Transformed Business Models Go Beyond Win-Win I LinkedIn. Available online: https://www.linkedin.com/pulse/ digital-transformed-business-models-go-beyond-win-win-bill-schmarzo/ (accessed on 9 April 2021).

23. Santhanam, N.; Varanasi, S.; Surana, K.; Jacobson, Z.; Zegeye, A. McKinsey on Food Processing \& Handling Ripe for Disruption? 2018. Available online: https://www.mckinsey.com/ \{\}/media/mckinsey/industries/advanced\%20electronics/our\%20 insights / whats $\% 20$ ahead $\% 20$ for $\% 20$ food $\% 20$ processing $\% 20$ and $\% 20$ handling/mckinsey-on-food-processing-and-handlingripe-for-disruption.ashx (accessed on 9 April 2021).

24. Gray, B.; Babcock, L.; Tobias, L.; McCord, M.; Herrera, A.; Cadavid, R. Digital Farmer Profiles: Reimagining Smallholder Agriculture; Grameen Foundation: Washington, DC, USA, 2018.

25. Chang, Y.-W.; Lin, K.-P.; Shen, C.-Y. Blockchain Technology for E-Marketplace. In Proceedings of the 2019 IEEE International Conference on Pervasive Computing and Communications Workshops (PerCom Workshops), Kyoto, Japan, 11-15 March 2019; IEEE: New York, NY, USA, 2019; pp. 429-430.

26. Parikh, S.M.; Patel, N.M.; Prajapati, H.B. Resource Management in Cloud Computing: Classification and Taxonomy. arXiv 2017, arXiv:1703.00374.

27. Miranda, J.; Ponce, P.; Molina, A.; Wright, P. Sensing, Smart and Sustainable Technologies for Agri-Food 4.0. Comput. Ind. 2019, 108, 21-36. [CrossRef]

28. Kayikci, Y.; Subramanian, N.; Dora, M.; Bhatia, M.S. Food Supply Chain in the Era of Industry 4.0: Blockchain Technology Implementation Opportunities and Impediments from the Perspective of People, Process, Performance, and Technology. Prod. Plan. Control 2020, 1-21. [CrossRef]

29. Llanes, R.P. E-Commerce as a Tool to Boost the Development of Cuban Agribusiness Companies. Sci. Tech. 2020, 25, 120-126. [CrossRef]

30. Gnauer, C.; Pichler, H.; Schmittner, C.; Tauber, M.; Christl, K.; Knapitsch, J.; Parapatits, M. A Recommendation for Suitable Technologies for an Indoor Farming Framework. e i Elektrotechnik Inf. 2020, 137, 370-374. [CrossRef]

31. Das Nair, R.; Landani, N. Making Agricultural Value Chains More Inclusive through Technology and Innovation; World Institute for Development Economic Research (UNU-WIDER): Helsinki, Finland, 2020.

32. The Strategic Business Value of the Blockchain Market I McKinsey. Available online: https://www.mckinsey.com/businessfunctions/mckinsey-digital/our-insights/blockchain-beyond-the-hype-what-is-the-strategic-business-value\# (accessed on 9 April 2021). 
33. Caiazza, R.; Bigliardi, B. Web Marketing in Agri-Food Industry: Challenges and Opportunities. Trends Food Sci. Technol. 2020, 103, 12-19. [CrossRef]

34. Oltra-Mestre, M.J.; Hargaden, V.; Coughlan, P.; Segura-García del Río, B. Innovation in the Agri-Food Sector: Exploiting Opportunities for Industry 4.0. Creat. Innov. Manag. 2021, 30, 198-210. [CrossRef]

35. Kataike, J.; Aramyan, L.H.; Schmidt, O.; Molnár, A.; Gellynck, X. Measuring Chain Performance beyond Supplier-Buyer Relationships in Agri-Food Chains. Supply Chain Manag. Int. J. 2019, 24, 484-497. [CrossRef]

36. Kramer, M.P.; Bitsch, L.; Hanf, J. Blockchain and Its Impacts on Agri-Food Supply Chain Network Management. Sustainability 2021, 13, 2168. [CrossRef]

37. Joiner, J.; Okeleke, K. E-Commerce in Agriculture: New Business Models for Smallholders' Inclusion into the Formal Economy. Available online: https://www.gsma.com/mobilefordevelopment/wp-content/uploads/2019/05/E-commerce_-in_agriculture_ new_business_models_for_smallholders_inclusion_into_the_formal_economy.pdf (accessed on 9 April 2021).

38. Osterwalder, A.; Pigneur, Y. Business Model Generation: A Handbook for Visionaries, Game Changers, and Challengers; John Wiley \& Sons: Hoboken, NJ, USA, 2010.

39. Annosi, M.C.; Brunetta, F.; Daniel, D. Transitioning to Circular Economy: How Do Business Models Evolve? Comp. Co. Food Ind. 2021. Available online: https://luissuniversitypress.it/wp-content/uploads/2021/03/Luiss-Business-Cases_Annesi_Brunetta_ Daniel_2021.pdf (accessed on 14 May 2021).

40. Tim O’Reilly Quotes. Available online: https://www.brainyquote.com/quotes/tim_oreilly_219559 (accessed on 9 April 2021).

41. Spanaki, K.; Karafili, E.; Sivarajah, U.; Despoudi, S.; Irani, Z. Artificial Intelligence and Food Security: Swarm Intelligence of AgriTech Drones for Smart AgriFood Operations. Prod. Plan. Control 2021, 1, 1-19. [CrossRef]

42. Spanaki, K.; Sivarajah, U.; Fakhimi, M.; Despoudi, S.; Irani, Z. Disruptive Technologies in Agricultural Operations: A Systematic Review of AI-Driven AgriTech Research. Ann. Oper. Res 2021. [CrossRef]

43. Duan, Y.; Fu, G.; Zhou, N.; Sun, X.; Narendra, N.C.; Hu, B. Everything as a Service (XaaS) on the Cloud: Origins, Current and Future Trends. In Proceedings of the 2015 IEEE 8th International Conference on Cloud Computing, New York, NY, USA, 27 June-2 July 2015; pp. 621-628.

44. De Bernardi, P.; Azucar, D. Innovative and Sustainable Food Business Models. In Innovation in Food Ecosystems: Entrepreneurship for a Sustainable Future; Contributions to Management Science; De Bernardi, P., Azucar, D., Eds.; Springer International Publishing: Cham, Switzerland, 2020; pp. 189-221. ISBN 978-3-030-33502-1.

45. Amin, M.R.; Zuhairi, M.; Saadat, M. Enhanced Blockchain Transaction: A Case of Food Supply Chain Management. J. Eng. Appl. Sci. 2019, 15, 99-106. [CrossRef]

46. Marecki, K.; Wójcik-Czerniawska, A.E. The Use of Blockchain Technology to Improve the Food Supply Chain. Available online: https:/ /ageconsearch.umn.edu/record/308135 (accessed on 23 April 2021).

47. Guzueva, E.R.; Vezirov, T.G.; Beybalaeva, D.K.; Batukaev, A.A.; Chaplaev, K.G. The Impact of Automation of Agriculture on the Digital Economy. IOP Conf. Ser. Earth Environ. Sci. 2020, 421, 022047. [CrossRef]

48. Tsolakis, N.; Bechtsis, D.; Bochtis, D. AgROS: A Robot Operating System Based Emulation Tool for Agricultural Robotics. Agronomy 2019, 9, 403. [CrossRef]

49. Zhao, G.; Liu, S.; Lopez, C.; Lu, H.; Elgueta, S.; Chen, H.; Boshkoska, B.M. Blockchain Technology in Agri-Food Value Chain Management: A Synthesis of Applications, Challenges and Future Research Directions. Comput. Ind. 2019, 109, 83-99. [CrossRef]

50. Medici, M.; Pedersen, S.M.; Carli, G.; Tagliaventi, M.R. Environmental Benefits of Precision Agriculture Adoption. Econ. Agro-Aliment. 2019, 21, 637-656. [CrossRef]

51. Albiero, D.; de Paulo, R.L.; Junior, J.C.F.; da Silva Gomes Santos, J.; Melo, R.P. Agriculture 4.0: A Terminological Introduction. Rev. Ciência Agronômica 2020, 51, 1-8.

52. Kotarba, M. Digital Transformation of Business Models. Found. Manag. 2018, 10, 123-142. [CrossRef]

53. Joyce, A.; Paquin, R.L. The Triple Layered Business Model Canvas: A Tool to Design More Sustainable Business Models. J. Clean. Prod. 2016, 135, 1474-1486. [CrossRef]

54. Fitriasari, F. How Do Small and Medium Enterprise (SME) Survive the COVID-19 Outbreak? J. Inov. Ekon. 2020, 5, 53-62. [CrossRef] 